\title{
The Influence of Knowledge and Attitude Factors on Compliance with Drinking Oat (Anti-Tuberculosis Drugs) In Patients with Lung Tuberculosis in the Regional Public Hospital, dr. Husni Thamrin Natal Sumatera Utara
}

\author{
Safarianti $^{1}$, Rolan Ronaldo ${ }^{2}$, Rina Suryani Oktari ${ }^{3}$ \\ ${ }^{1,2,3}$ Faculty of Medicine, Syiah Kuala University, Banda Aceh
}

\begin{abstract}
Pulmonary Tuberculosis (TB) is a lung infection caused by bacillus bacteria called Mycobacterium tuberculosis. MTB generally attacks the lungs and carries a very high risk of transmission. Patients with TB are potentially non-adherent totake antituberculosis drugs (OAT) regularly as directed due to a long period of medication. Factors affecting ATD taking compliance include knowledge and attitudes of pulmonary $T B$ patients. This study aimed to determine the relationship of knowledge and attitude of tuberculosis patients with compliance of ATD drinking in RSUD dr. Husni Thamrin Natal Regency Mandailing Natal. The research was conducted in dr. Husni Thamrin Natal. This research is an observational analytic by cross sectional design which involved 57 participants taken with consecutive sampling method. Data were processed into Spearman ' $s$ correlation test. The result showed that knowledge ( $p$ value $=0,000)$ and attitude $(p$ value $=0,000)$ related to OAT drinking compliance. This research had proven that the knowledge and attitudes affected OAT drinking compliance of the TB outpatient in RSUD dr. Husni Thamrin Natal, Mandailing Natal Regency.
\end{abstract}

Keywords: knowledge; attitude; compliance with OAT drinking and tuberculosis

\section{Introduction}

Pulmonary tuberculosis is Infectious diseases of the lungs caused by Mycobacterium tuberculosis with a very high risk of transmission $(1,2)$ The World Health Organization (WHO) estimates that in 2016 there are an estimated 10.4 million new cases of pulmonary TB worldwide. $(3,4)$ Pulmonary TB disease is the second largest infectious disease contributor to adult mortality, which causes approximately 1.8 million deaths in the world. According to the WHO report in 2015, the prevalence of pulmonary TB in Indonesia is estimated that there are 1 million new TB cases per year (399 per 100,000 population) with 100,000 deaths per year (41 per 100,000 population). The rate of notification of pulmonary TB cases was reported as 129 per 100,000 population of all cases. The total number of cases was 324,539 , of which 314,965 were new cases.

Based on data from Indonesia's health profile in 2016, the incidence of pulmonary TB in North Sumatra Province ranks 4th highest in Indonesia with a total of 11,771 cases.(6.7)The initial survey conducted at dr. Husni Thamrin Natal, Mandailing Natal Regency, found that pulmonary TB disease was quite high. In 2016, pulmonary TB disease was the top 10 outpatient diseases with a total of 108 cases.

Pulmonary TB treatment requires a long period of about 6 to 9 months. All TB sufferers have the potential to not adhere to treatment and take medication regularly according to the instructions and consume it according to the specified time in a row without breaking. Non-compliance with treatment will lead to failure and relapse, resulting in resistance and continuous disease transmission. This can increase the risk of morbidity, mortality and drug resistance both in patients and in the wider community. Another 
consequence of noncompliance with long-term treatment is deteriorating health and increasing costs of care. (2.8)

Many factors affect compliance with taking anti-tuberculosis (OAT) drugs for pulmonary tuberculosis patients, including patient knowledge about pulmonary tuberculosis, patient attitudes about pulmonary tuberculosis, family support, socioeconomic conditions, whether or not a drug swallow supervisor (PMO) and the distance between the patient's house and sick. $(2,9,10)$

This study aims to determine whether knowledge and attitude factors can affect adherence to taking anti-tuberculosis (OAT) drugs in outpatient pulmonary polyclinic RSUD dr. Husni Thamrin Natal, Mandailing Natal Regency.

\section{Research Methods}

This research is an observational analytic study with cross sectional type. The study population was all pulmonary TB patients inLung Polyclinic RSUD dr. Husni Thamrin Natal, Mandailing Natal Regency. The research sample was respondents who met the inclusion criteria and did not meet the exclusion criteria. $(11,12)$ The inclusion criteria were pulmonary tuberculosis patients who were carrying out early and advanced treatment, respondents aged $\geq 18$ years, and willing to become respondents. The exclusion criteria were patients with pulmonary tuberculosis who had mental or language limitations that could affect informed consent and patients who were not cooperative when filling out the questionnaire.

The sampling technique is non-probability sampling with consecutive sampling method. The sample size is obtained from the Slovin formula to the total population, namely 57 people. The data were collected through guided questionnaire interviews and analyzed using the Spearman Rank correlation test. The spearman rank correlation test was conducted to see the relationship between each research variable.

\section{Results and Discussion}

The study was conducted on patients with pulmonary TB aged $\geq 18$ years atPulmonary polyclinic RSUD dr. Husni Thamrin Natal, Mandailing Natal Regency. Data collection started from the beginning of January to the end of February 2018 and found 57 respondents with pulmonary tuberculosis who were carrying out early and advanced stages of treatment.

\subsection{Results}

\section{a. Respondent Characteristics}

The characteristics of the respondents in this study are presented in table 1 below.

Table 1. Characteristics of Respondents

\begin{tabular}{ccc}
\hline $\begin{array}{c}\text { Characteristics } \\
\text { Respondents }\end{array}$ & $\begin{array}{c}\text { Frequency } \\
(\mathrm{n}=100)\end{array}$ & $\begin{array}{c}\text { Percentage } \\
(\%)\end{array}$ \\
\hline
\end{tabular}




\begin{tabular}{lcc}
\hline Age (Years) & & \\
$17-25$ & 5 & 8.8 \\
$26-35$ & 15 & 26.3 \\
$36-45$ & 20 & 35.1 \\
$46-55$ & 9 & 15.8 \\
Gender & & \\
Male & 31 & 54.4 \\
Women & 26 & 45.6 \\
Education & & \\
SD & 8 & 14.0 \\
Junior High & 12 & 21.1 \\
High school & 29 & 50.9 \\
PT & 8 & 14.0 \\
Profession & & \\
Teacher & 2 & 3.5 \\
IRT & 12 & 21.1 \\
Head of village & 1 & 1.8 \\
Retired & 2 & 3.5 \\
Farmer & 10 & 17.5 \\
Civil servants & 1 & 1.8 \\
Police & 1 & 1.8 \\
Does not work & 10 & 17.5 \\
Builders / & 5 & 8.8 \\
Laborers & 13 & 22.8 \\
entrepreneur & & \\
\hline
\end{tabular}

Table 1 shows that the highest frequency of pulmonary TB patients is aged 36-45 years $(35.1 \%)$ and the lowest frequency is respondents aged 56-65 years (5.3\%).

The distribution of frequency based on gender shows that the highest frequency is male, namely 31 respondents $(54.4 \%)$ and the lowest frequency is female, 26 people $(45.6 \%)$. The distribution of the respondents' education frequency shows that the highest frequency is respondents with high school education, namely 29 people $(50.9 \%)$ and the lowest frequency is respondents with elementary and university education, namely 8 people $(14.0 \%)$. The frequency distribution of the respondent's work shows that the highest frequency is respondents with self-employed jobs, namely 13 people (22.8\%) and the lowest frequency is respondents with police, village head and civil servant jobs, namely 1 person $(1.8 \%)$

Sex was devided into two catagories: male and female, and religion was also devided into two: muslims and non-muslims. Age was devided into four groups: 31-40 years old, 41-50 years old, 51-60 years old, and >60 years old. Formal education was defined as the completed formal education obtained, and catagorised into four groups: No formal education (either having no formal education at all or did not complete elementary school), elementary school, middle school, and high school.

Duration of practice was divided into three categories: $<5$ years, 5-10 years, and $>10$ years. Availability of practise permit was categorised into two: have and not have. Therapeutic methods were divided into three groups: the use of traditional massages, splints, and herbal mixtures; the use of incantations; and a combination of the two. Source of knowledge about bone setting were categorized into three groups: supernatural powers, ancestral heritage, and apprenticeships. The utilisation of supportive medical assistance was investigated by asking questions about whether or not the bone setters use supportive 
medical examination such as X-rays or medical treatment like pain killers or vitamins. Univariate analysis was employed to analyze the data.

\section{b. Distribution of Knowledge Frequency of Patients with Pulmonary Tuberculosis}

The results of research regarding the distribution of respondents' knowledge are presented in table 2 below.

Table 2. Knowledge Frequency Distribution

\begin{tabular}{ccc}
\hline Knowledge & $\begin{array}{c}\text { Frequency } \\
(\mathrm{n}=100)\end{array}$ & $\begin{array}{c}\text { Percentage } \\
(\%)\end{array}$ \\
\hline Very less & 2 & 3.5 \\
Less & 12 & 21.1 \\
Good & 22 & 38.6 \\
Very good & 21 & 36.8
\end{tabular}

In Table 2, it can be seen that 57 pulmonary TB respondents who went to Pulmonary polyclinic RSUD dr. Husni Thamrin Natal, 38.6\% have good knowledge. As many as $36.8 \%$ had very good knowledge, and the remaining $21.1 \%$ and $3.5 \%$ had poor knowledge of tuberculosis.

\section{c. Attitude Distribution of Pulmonary Tuberculosis Patients}

The results of the study regarding the frequency distribution of the respondents' attitudes are presented in table 3 below.

Table 3. Distribution of Attitude Frequency

\begin{tabular}{lcc}
\hline Attitude & $\begin{array}{c}\text { Frequency } \\
(\mathrm{n}=100)\end{array}$ & $\begin{array}{c}\text { Percentage } \\
(\%)\end{array}$ \\
\hline Very less & 1 & 1.8 \\
Less & 10 & 17.5 \\
Good & 21 & 36.8 \\
Very good & 25 & 43.9
\end{tabular}

Based on Table 3 it can be seen that of the 57 pulmonary TB respondents who went to Pulmonary polyclinic RSUD dr. Husni Thamrin Natal, Mandailing Natal Regency, as much as $43.9 \%$ have a very good attitude regarding obedience to drinking OAT.

\section{d. Compliance with OAT Drinking in Patients with Pulmonary Tuberculosis}

The results of the study regarding adherence to drinking OAT in patients with pulmonary tuberculosis are presented in table 4 . below.

Table 4. Frequency Distribution of Compliance with OAT Drinking

\begin{tabular}{lcc}
\hline Obedience & $\begin{array}{c}\text { Frequency } \\
(\mathrm{n}=100)\end{array}$ & $\begin{array}{c}\text { Percentage } \\
(\%)\end{array}$ \\
\hline $\begin{array}{l}\text { Low } \\
\text { compliance }\end{array}$ & 6 & 10.5 \\
$\begin{array}{l}\text { Medium } \\
\text { compliance }\end{array}$ & 14 & 24.6 \\
$\begin{array}{l}\text { High } \\
\text { compliance }\end{array}$ & 37 & 64.9
\end{tabular}


Distribution of Compliance with OAT Drinking in Table 4 shows that 57 pulmonary TB respondents who went to the pulmonary polyclinic of dr. Husni Thamrin Natal, Mandailing Natal Regency, $64.9 \%$ of respondents has obedience to drinking OAT in the high category.

\section{e. Relationship between Knowledge and Compliance with OAT Drinking for Patients with Pulmonary Tuberculosis}

The results of the bivariate analysis of the research results using the Spearman Rank test on the variable knowledge and compliance with drinking OAT in patients with pulmonary tuberculosis are presented in table 5 . below.

Table 5. Bivariate Analysis (Spearman Rank Test) Relationship between Knowledge and Compliance with OAT Drinking

\begin{tabular}{|c|c|c|c|c|c|c|c|c|c|}
\hline \multicolumn{10}{|c|}{ OAT Drinking Compliance } \\
\hline \multirow{2}{*}{ Knowledge } & \multicolumn{2}{|c|}{ Low } & \multicolumn{2}{|c|}{ Moderate } & \multicolumn{2}{|c|}{ High } & \multicolumn{2}{|c|}{ Total } & $P$ \\
\hline & $\mathrm{N}$ & $\%$ & $\mathrm{~N}$ & $\%$ & $\mathrm{~N}$ & $\%$ & $\mathrm{~N}$ & $\%$ & \\
\hline Very less & 0 & 0 & 1 & 7,1 & 1 & 2.7 & 2 & 3.5 & \\
\hline Less & 5 & 83.3 & 7 & 50 & 0 & 0 & 12 & 21.1 & 0.000 \\
\hline Good & 1 & 16.7 & 6 & 42.9 & 15 & 40.5 & 22 & 38.6 & \\
\hline Very good & 0 & 0 & 0 & 0 & 21 & 56.8 & 21 & 36.8 & \\
\hline Total & 6 & 10.5 & 14 & 24.6 & 37 & 64.9 & 57 & 100 & \\
\hline
\end{tabular}

The results of the bivariate test analysis in Table 5 above show that respondents who had very good knowledge were $56.8 \%$ and had high compliance with drinking OAT, while respondents who had very little knowledge of $7.1 \%$ had compliance with drinking OAT in the moderate category.

The results of statistical tests with the Spearman-rank test obtained a p-value of $0.000 \quad(\alpha<0.05)$ which indicates that there is a relationship between knowledge and compliance with OAT drinking of pulmonary TB patients at the Lung Polyclinic of dr. Husni Thamrin Natal, Mandailing Natal Regency.

Table 6. Bivariate Analysis (Spearman Rank Test) Relationship between Attitudes and Compliance with OAT Drinking

\begin{tabular}{llllllllll}
\hline \multicolumn{1}{c}{ OAT Drinking Compliance } \\
\hline \multirow{2}{*}{ Attitude } & Low & & Moderate & High & Total & $\begin{array}{c}\text { P } \\
\text { value }\end{array}$ \\
\cline { 2 - 8 } & $\mathrm{N}$ & $\%$ & $\mathrm{~N}$ & $\%$ & $\mathrm{~N}$ & $\%$ & $\mathrm{~N}$ & $\%$ & \\
\hline Very & 1 & 16.7 & 0 & 0 & 0 & 0 & 1 & 1.8 \\
less & & & & & & & & & \\
\hline
\end{tabular}




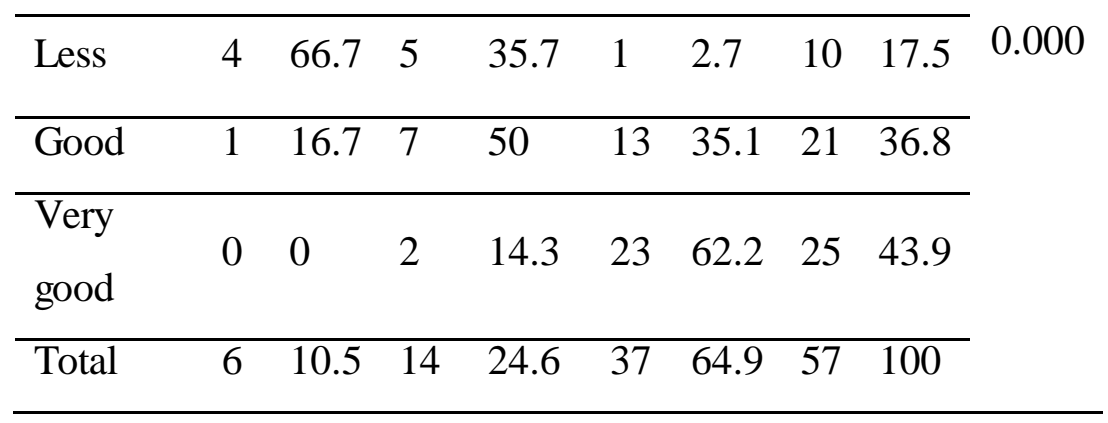

Based on Table 6 above, it can be found that $62.2 \%$ of respondents who have a very good attitude are obedient to drinking OAT, while the respondents who have a very bad attitude are $16.7 \%$ of compliance with drinking OAT in the low category.

The results of statistical tests with the Spearman-rank test obtained a p-value of $0.000(\alpha<0.05)$ which indicates that there is a relationship between attitude and compliance with OAT drinking of pulmonary TB patients in the Lung Polyclinic of dr. Husni Thamrin Natal, Mandailing Natal Regency.

\subsection{Discussion}

This study produces a description of respondents based on age, gender, occupation and education for 57 respondents. The results of the study in table 4.1 show that the highest pulmonary TB respondents are in the age range 36-45 years (35.1\%). This is in line with Dotulong's research which shows the highest number of pulmonary TB respondents in the age range 15-54 years (67\%) and in line with Ariani's research which shows the highest number of pulmonary TB respondents at $\leq 60$ years of age $(78 \%) .{ }^{29)}{ }^{(30)}$ The Dotulong study, 2015, assumes that the population in the 15-55 year age group has very high mobility so that the possibility of being exposed to Mycobacterium tuberculosis is greater. Population at this age has the opportunity to experience endogenous reactivity, namely the reactivation of an infectious agent that is dormant in the body. (13.14)

Based on the results of the research in Table 1, it is also known that the majority of pulmonary TB respondents were male $(54.4 \%)$. This is in line with Siswanto's research which showed that the highest number of pulmonary TB respondents was male $(69.2 \%)$ and in line with the Septia study which showed that the highest number of pulmonary TB respondents was male $(74.14 \%)$. $(15)$, 16) Pulmonary TB disease tends to be higher in men than women, because smoking, going out at night and drinking alcohol is more common in men so that it can reduce the body's defense system, and are more easily exposed to the agents that cause pulmonary TB. (17.18)

The results of this study as shown in table 1 also show that most of the respondents have high school education (50.9\%). This is in line with Prihantana's research which showed that the highest number of pulmonary TB respondents had high school education $(52.5 \%)$, besides Siswanto's research also mentioned the same thing, namely the highest number of pulmonary TB respondents with high school education $(38.5 \%)$. $(15,19)$ The level of patient education can increase adherence, as long as that education is an active education that is obtained independently, through certain stages. $(14,16,20)$

Most of the respondents in this study worked as entrepreneurs $(22.8 \%)$. This is in line with Sari's research which shows that the highest number of pulmonary TB respondents is found in people who work (54.5\%). (2) Jobs located in a crowded environment and many people can increase the risk of pulmonary TB infection. These working conditions make it easier for someone of productive age to suffer more easily and 
suffer from pulmonary TB due to exposure to infectious agents during work, including Mycobacterium tuberculosis. (13)

\section{a. Relationship of Knowledge and Attitudes of Pulmonary Tb Patients on Compliance with Oat Drinking}

The results showed that respondents with good knowledge were also followed by high obedience to drinking OAT, namely $40.5 \%$ and a large proportion pulmonary tuberculosis patients have above average knowledge. In this study, respondents still lacked knowledge. This is probably due to the lack of information obtained from health care workers at hospitals and health centers regarding the treatment of pulmonary TB disease so that there are still some respondents who do not comply with taking OAT drinking therapy. Another possibility is that the patient's knowledge is good, but pulmonary TB treatment which takes a long time makes the patient feel bored in undergoing therapy so that it affects compliance with taking OAT in pulmonary TB patients.

This study shows that there is a significant relationship between knowledge and compliance with OAT drinking of pulmonary TB patients in the Lung Polyclinic of dr. Husni Thamrin Natal, Mandailing Natal Regency ( $\mathrm{p}$ value $=0,000$ ). The results of this study are in accordance with the results of research conducted by Slanga 2013 which states that there is a relationship between knowledge and compliance with OAT drinking of pulmonary TB patients at the DOTS Polyclinic of RSUDZA Banda Aceh and research conducted by Siswanto 2013 which states that there is a relationship between knowledge and compliance with drinking OAT. at the Andalas Health Center, Padang City. Research conducted by Sari 2011 at Puskesmas Amplas Kota Medan also showed that the variable that had an effect on the level of medication adherence was knowledge $(p=0.012){ }^{(15,21,22)}$ This is different from Wulandari's 2011 research at the Lung Poli RSUP H. Adam Malik Medan which stated that there was no relationship between knowledge and regularity in taking OAT. ${ }^{(20)}$

The knowledge process involves 3 aspects, namely the process of obtaining information, the process of transformation and the process of evaluation. The new information obtained is a substitute for previously acquired knowledge or a complement to previous information. ${ }^{(23,24)} \mathrm{A}$ person's knowledge can be influenced by a person's education level, because the higher a person's education level, the better his knowledge. Acceptance of new information and mastery of knowledge obtained by individuals is related to the level of education that is being taken. Individuals with high levels of education are expected to have sufficient knowledge about the factors related to compliance with OAT drinking in patients with pulmonary TB. ${ }^{(23,25,26)}$

The results of the data analysis showed that respondents who had a very good attitude were also accompanied by high compliance with drinking OAT by $62.2 \%$. The results showed that most of the patients' attitudes about pulmonary tuberculosis were very good (43.9\%), but there were still respondents who were very less likely because there was still a lack of information obtained from health care workers at hospitals and puskesmas about the dangers of pulmonary TB disease and how correct treatment so that there are still some respondents who do not comply with taking OAT.

This study shows that there is a relationship between attitude and compliance with OAT drinking in patients with pulmonary tuberculosis in the Lung Polyclinic of dr. Husni Thamrin Natal, Mandailing Natal Regency ( $p$ value $=0,000$ ). The results of this study are in line with research conducted by Gendhis in 2011 which stated that there was a relationship between patient attitudes and adherence to taking medication for pulmonary TB patients at BKPM Pati, but contrary to research conducted by Doni in 2007 at 
Puskesmas Jatibarang, Indramayu District, which showed that the respondents who have a disapproving attitude does not affect their compliance in taking OAT ${ }^{\text {(24.27) }}$

The existence of a relationship between attitude and adherence to taking medication for pulmonary tuberculosis patients means that there is a tendency that a positive attitude increases compliance behavior. Attitude greatly affects one's compliance in drinking OAT because attitude is a readiness or willingness to act and not an implementation of certain motives. Attitudes have levels based on intensity, including being willing to accept a given stimulus, providing responses or answers to questions given, giving positive values to objects or stimuli, in the sense of discussing them with others, even inviting or influencing and encouraging others to respond. The highest level of attitude is to be responsible for what he has believed. $(2,24,26,28)$

\section{Conclusion}

The result of research conducted in at the Lung Polyclinic RSUD dr. Husni Thamrin Natal, Mandailing Natal Regency shows that knowledge and attitude are important factors that can influence compliance with OAT drinking of pulmonary TB patients.

It needs continuous effort by North Sumatra City Health Office so that it should be able to maintain and improve health promotion and socialization about the prevention of pulmonary TB disease and the importance of adhering to drinking OAT regularly. SufferersPulmonary tuberculosis is also advised to actively read information media in the form of brochures, papers, or books related to pulmonary tuberculosis to increase knowledge and improve compliance with OAT drinking to facilitate the healing process of pulmonary TB disease. Further research needs to be done to assess the characteristics of pulmonary tuberculosis patients in more depth regarding the diagnostic characteristics of pulmonary TB patients both bacteriologically and diagnostically.

\section{References}

1. Mulyadi, Suangkupon R DI. Profil Penderita Tuberkulosis Paru di Pesisir Pantai Aceh Barat Daya ( Kajian di Puskesmas Blangpidie ). J Respirologi Indones. 2011;31(2):105-8.

2. Sari ID, Mubasyiroh R, Supardi S. Hubungan Pengetahuan dan Sikap dengan Kepatuhan Berobat pada Pasien TB Paru yang Rawat Jalan di Jakarta Tahun 2014. Media Litbangkes. 2016;26(4):243-8.

3. Burhan E. Tuberkulosis Multi Drug Resistance (TB-MDR). Maj Kedokt Indones. 2010;60(12):535-6.

4. Kemenkes. Pelatihan Penanggulangan Tuberkulosis Bagi Petugas Kesehatan di Fasilitas Kesehatan Tingkat Pertama: Materi Inti 1 Penemuan Pasien Tuberkulosis. 2017;1-53.

5. Hudoyo A. Jurnal Tuberkulosis Indonesia. J Tuberkulosis Indones. 2012;8.

6. Kemenkes. Peraturan Menteri Kesehatan Republik Indonesia Nomor 67 Tahun 2016 tentang Penanggulangan Tuberkulosis. 2016;

7. Hardhana B, Budiono CS, Kurniasih N, Manullang E V, Susanti MI, Pangribowo S, et al. Data dan Informasi Profil Kesehatan Indonesia 2016. 2017.

8. Junita.F. Anti Tuberculosis Pada Pasien Tuberculosis Paru di Puskesmas Kecamatan Jatinegara Tahun 2012. Sekolah Tinggi Ilmu Kesehatan Medistra Indonesia; 2012.

9. Edi N, Sukoco W. Hubungan Antara Perilaku Pencegahan dan Kepatuhan Berobat Penderita TB di Indonesia. Bul Penelit Sist Kesehat. 2011;14(1):68-74. 
10. Liu Y, Pang C, Liu Y, Sun X, Li X, Jiang S. Association Between MultidrugResistant Tuberculosis and Risk Factors in China: Applying Partial Least Squares Path Modeling. PLoS One. 2015;1-13.

11. Notoatmodjo. Metodologi Penelitian Kesehatan. Jakarta; 2010;15-48.

12. Arikunto S. Prosedur Penelitian. edisi 6. Mahasatya PA, editor. Jakarta: Penerbit Rineka Cipta; 2010. 130-131 p.

13. Dotulong J. Hubungan Faktor Risiko Umur, Jenis Kelamin dan Kepadatan Hunian Dengan Kejadian Penyakit TB Paru Di Desa Wori Kecamatan Wori. J Kedokt Komunitas dan Trop. 2015;3(2).

14. Ariani Niwayan R. Faktor-faktor Yang Berhubungan Dengan Keteraturan Minum Obat Penderita Tuberkulosis Paru Di Wilayah Kerja Puskesmas Modayag, Kabupaten Bolaang Mongondow Timur. JIKMU. 2015;5.

15. Siswanto Iman Y. Hubungan Pengetahuan dan Dukunga Keluarga Dengan Kepatuhan Minum Obat Anti Tuberkulosis Paru di Puskesmas Andalas Kota Padang. Kesehat Andalas. 2015;

16. Septia Asra RS. Hubungan Dukungan Keluarga Dengan Kepatuhan Minum Obat Pad Penderita TB Paru. PSIK. 2013;1.

17. Pasek Suadnyani, Suryani Nunuk MP. Hubungan Persepsi Pengawas dan Tingkat Pengetahuan Penderita Tuberkulosis Dengan Kepatuhan Pengobatan di Wilayah Kerja Puskesmas Buleleng 1. Magister Kedokt Kel. 2013;Vol 1.

18. Yulianingsih Y, Tinggi S, Kesehatan I. Pelaksanaan Pencegahan Penularan Tuberkulosis Paru oleh Keluarga di UPTD Kesehatan Ciamis Tahun 2016. 2016;

19. Prihantana Anna WSH. Hubungan Pengetahuan Dengan Tingkat Kepatuhan Pengobatan pada Pasien Tuberkulosis Di RSUD dr. Soehadi Prijonegoro Sragen. J Farm Sains dan Prakt. 2016; Vol II.

20. Wulandari P. Pengaruh Tingkat Pendidikan Dan Pengetahuan Tentang Tuberkulosis Paru Dengan Keteraturan Minum Obat Anti Tuberkulosis Pada Penderita Tuberkulosis Paru Di Poli Paru RSUP. H. Adam Malik Medan. Universitas Sumatera Utara; 2011.

21. Slanga P. Hubungan Pengetahuan, Sikap dan Penyuluhan dengan Kepatuhan Minum OAT pada Penderita TB Paru di Poliklinik Dots RSUDZA Banda Aceh. 2013.

22. Sari. Pengaruh Pengetahuan Penderita TB Paru, Faktor Pelayanan Kesehatan dan Pengawas Menelan Obat Terhadap Tingkat Kepatuhan Minum Obat di Puskesmas Amplas Kota Medan. Universitas Sumatera Utara; 2011.

23. Mubarak W. Promosi Kesehatan Untuk Kebidanan. Salemba Medika; 2011.

24. Gendhis I. Hubungan Antara Pengetahuan, Sikap Pasien Dan Dukungan Keluarga Dengan Kepatuhan Minum Obat Pada Pasien TB Paru Di BKPM Pati. Stikes Tolegorejo; 2011.

25. Rohmana Omay S. Faktor-Faktor pada PMO yang berhubungan dengan Kepatuhan Berobat Penderita TB Paru di Kota Cirebon. Kesehat Komunitas Indones. 2014;10.

26. Pameswari Puspa, Halim Auzal YL. Tingkat Kepatuhan Penggunaan Obat Pada Pasien Tuberkulosis di Rumah Sakit Mayjen H. A. Thalib Kabupaten Kerinci. Sains Farm dan Klin. 2016;2.

27. Doni A. Hubungan Tingkat Pengetahuan dan Sikap Penderita TB Paru Dengan Kepatuhan Minum Obat di Wilayah Kerja Puskesmas Jatibarang. Indramayu; 2007.

28. Wijaya I, Murti B SP. Hubungan Pengetahuan, Sikap dan Motivasi Kader Kesehatan Dengan Aktivitasnya Dalam Pengendalian Kasus Tuberkulosis di Kabupaten Buleleng. Magister Kedokt Kel. 2013;1. 